\title{
Effect of Fertilizers on the Sapogenin Yields of Dioscorea composita in Puerto Rico ${ }^{1}$
}

\author{
Héctor J. Cruzado, Herminio Delpin, and Franklin W. Martin ${ }^{2}$
}

\section{INTRODUCTION}

Medicinal yams, originally from the wilds of Mexico and Central America, are now being cultivated in Puerto Rico for both experimental and commercial purposes. The domestication of these yams will necessitate studies of the agronomic characteristics of the species as well as selection of the better wild types, followed by improvement by breeding. Studies of the effects of fertilizers on yields of sapogenin, which is used in the synthesis of steroidal drugs, are reported herein.

The experimental data on culture of the edible yams have been reviewed by Waitt $(5)^{3}$. A wide variety of manures and fertilizers have been tried with varying success. In general, the addition of nitrogen to the soil has been the single most beneficial treatment, but in most cases balanced fertilizers have been of more benefit. Irving ( 3 ) found reduction in yields in some cases following the use of phosphate. In Puerto Rico (1) the use of a 10-6-14 formula is recommended for the production of edible yams.

\section{MATERIALS AND METHODS}

Seedlings of Dioscorea composita Hemsl., USDA Plant Introduction 201783, from Mexico, were used. The seed were germinated in petri dishes, transplanted to pots, and held for about 4 months in the greenhouse prior to field planting.

The planting was made in a Cialitos clay soil in a field left to weed-fallow for several years prior to the experiment. This soil is a medium-heavy clay with poor internal drainage and known to vary considerably even in small areas. Because of high annual rainfall, 80 inches per year, the soil is leached and of less than average fertility. The soil was first plowed and disked. Furrows 1 foot deep were plowed in the position of the rows and subsequently ridges 1 foot high were built by disk over the furrows. Rows were spaced at 4-foot intervals and plants were set 2 feet apart in the rows. The vines were supported by 7 -foot bamboo poles. Individual plots were separated by guard rows and drainage ditches.

The experiment was designed as a randomized block with each treatment

1 In cooperation with New Crops Research Branch, USDA.

${ }^{2}$ Agronomists and Geneticist, Federal Experiment Station, Crops Research Division, ARS U.S. Department of Agriculture, Mayagüez, P.R., respectively.

${ }^{3}$ Italic numbers in parentheses refer to Literature Cited, p. 258. 
replicated four times. The treatments consisted of 582 pounds per acre, of ammonium sulfate, 582 per acre of superphosphate, and 200 per acre of potassium sulfate per year. The three fertilizers were compared in all combinations and with untreated controls. The yearly treatments were divided into three applications made during the rainy season.

The plants were harvested by hand-digging after 3 years of field growth. The tubers were cleaned and weighed. Representative, proportional sectors were removed from each plant for massing as composite samples. After fresh weight was measured again, the tubers were sliced into thin crosssections and mixed thoroughly. Finally, duplicate samples were taken for analysis of sapogenin content. The percentage of sapogenin of the dry weight of the tubers was determined by the method of Morris et al. (4) and the figures were used to determine yields per acre.

\section{RESULTS}

Plants grew well under all fertilizer regimens. There were no signs of chlorosis or nutrient deficiency which could be attributed to lack of or imbalance of fertilizer. At harvest the tubers varied in size from less than 2 to over 20 pounds, but the average weight was about 11.5 pounds. The smaller tubers were sometimes partly rotted, but this condition appeared to be scattered throughout the field and was not concentrated in tubers under particular treatments. In spite of careful precautions, a drainage problem occurred in replicate 4 (table 1), which may have leached the soil excessively and redistributed nutrients.

Yields in terms of fresh weight, dry weight, percentage of sapogenin, and total sapogenin are reported for the treatments in table 1 . Because the replicates differed significantly in some respects, their yields are also summarized (table 2).

With respect to effects of fertilizer treatment, three of the four analyses of variance revealed highly significant differences. Total sapogenin yield, the measurement of most importance, ranged from 433 to 840 pounds per acre (table 1). The highest yield was obtained when using the complete fertilizer, and the difference between this yield and that of the untreated control was significant. But other treatments were not significantly different, except for the phosphate treatment only, in which case a significant reduction in yield occurred.

Total yields may be divided into two components, percentage yields with respect to dry matter, and total dry matter. Although percentage of sapogenins ranged from 3.79 to 4.66 among the treatments, the differences were not statistically significant. It is interesting, however, that the unfertilized control yielded the highest percentage of sapogenin. Nevertheless, dry-matter as well as fresh-tuber yields were related to fertilizer treatments. 
Again, balanced fertilizer treatment significantly improved yields as compared with unfertilized controls. Single nutrient treatments reduced yields significantly in some cases.

The four replications differed significantly with respect to fresh and dry yields (table 2), but not with respect to percentage of and total sapogenin.

TABLE 1.-Yields of Dioscorea composita as influenced by fertilizer treatments

\begin{tabular}{|c|c|c|c|c|c|c|c|}
\hline \multirow[b]{2}{*}{ Treatment } & \multicolumn{2}{|c|}{ Fresh weight } & \multicolumn{2}{|c|}{ Dry weight } & \multirow{2}{*}{$\begin{array}{c}\text { Sapogenin } \\
\text { concentration }\end{array}$} & \multicolumn{2}{|c|}{ Total sapogenin } \\
\hline & $\begin{array}{c}\text { Hundred- } \\
\text { vecights/ } \\
\text { acre }\end{array}$ & Significance! & $\begin{array}{c}\text { Hundred- } \\
\text { weights/ } \\
\text { acre }\end{array}$ & Significance & & Pounds/acre & Significance \\
\hline & & & & & Percent & & \\
\hline NPK & 668.2 & a & 203.5 & $\mathbf{a}$ & 4.14 & 840.0 & $\mathbf{a}$ \\
\hline NP & 556.5 & $a b$ & 174.2 & $\mathbf{a b}$ & 4.27 & 709.2 & $\mathbf{a b}$ \\
\hline PK & 553.0 & ab & 171.0 & $a b$ & 4.06 & 684.2 & abc \\
\hline Control & 464.2 & bed & 138.8 & bc & 4.66 & 644.0 & bc \\
\hline NK & 526.8 & bc & 153.8 & bc & 3.79 & 581.2 & bed \\
\hline $\mathbf{K}$ & 453.8 & bed & 129.5 & cd & 4.27 & 550.0 & bcd \\
\hline $\mathbf{N}$ & 427.8 & cd & 124.5 & cd & 4.12 & 512.5 & cd \\
\hline $\mathbf{P}$ & 371.5 & d & 102.8 & d & 4.20 & 433.0 & d \\
\hline
\end{tabular}

1 Means that do not have letters in common are significantly different $(p=0.05)$, according to the method of Duncan (2).

TABLE 2.-Yields of Dioscorea composita as influenced by site of planting (replication)

\begin{tabular}{|c|c|c|c|c|c|c|}
\hline \multirow{2}{*}{ Replication } & \multicolumn{2}{|c|}{ Fresh weight } & \multicolumn{2}{|c|}{ Dry weight } & \multirow{2}{*}{$\begin{array}{c}\text { Sapogenin } \\
\text { concentration }\end{array}$} & \multirow{2}{*}{$\begin{array}{c}\text { Total } \\
\text { sapogenin }\end{array}$} \\
\hline & $\begin{array}{c}\text { Hundred- } \\
\text { weights/acre }\end{array}$ & Significance ${ }^{1}$ & $\begin{array}{c}\text { Hundred- } \\
\text { weights/acre }\end{array}$ & Significance & & \\
\hline & & & & & Percent & Lb./acre \\
\hline 1 & 544.9 & $a b$ & 157.6 & $a b$ & 3.88 & 608.2 \\
\hline 2 & 594.1 & $\mathrm{a}$ & 176.6 & $\mathrm{a}$ & 4.08 & 705.8 \\
\hline 3 & 475.5 & bc & 137.8 & bc & 4.28 & 591.8 \\
\hline 4 & 396.4 & c & 127.0 & c & 4.51 & 571.4 \\
\hline
\end{tabular}

${ }^{1}$ Means that do not have letters in common are significantly different $(p=0.05)$. Field relationship of replications: 4-3, 2,1 .

The replicate with highest percentage of sapogenin, but the lowest fresh and dry weight was No. 4, the replicate subject to flooding and poor drainage.

\section{DISCUSSION}

Efficiency of the test was reduced by the high level of variability among the materials (coefficient of variation for total sapogenin equals 17.8 
percent). Part of this variability resulted from choice of site, as demonstrated by the significant differences among replications for fresh- and dryweight measurements. Differences among replications with respect to percentage of sapogenin and total sapogenin were subsignificant. Part of the variability was also caused by the use of seedlings and their segregation for the traits measured. With the use of asexually propagated plants and more uniform soil, it should be possible to reduce these sources of error. Finally, part of the variability was attributable to an as yet unidentified tuber rot.

Nevertheless, the significant differences among the treatments suggest that nutrition of the medicinal yams is of importance. The 30-percent increase of total yields over controls resulting from complete fertilization can be considered a worthwhile return. This increase resulted from the effects of fertilizer on fresh and dry weights, rather than percentage of sapogenin, which was little if any affected. Although yields as percentage of sapogenin were not significantly affected by fertilization treatments, the substantial difference between treatment means suggests that such effects should be tested further.

The experiment demonstrated also that $D$. composita needs a balanced fertilizer, as all incomplete combinations yielded less than the complete. In addition, the data suggest that unbalanced fertilization with a single nutrient may actually reduce yields. Moreover, there was no evidence to show that any single nutrient was either more necessary or more harmful than any other.

\section{SUMMARY}

Seedlings of Dioscorea composita were treated with various combinations of ammonium sulfate, superphosphate, and potassium sulfate over a 3-year period. The tubers of the resulting plantings were tested for sapogenin content. Complete fertilization increased the sapogenin yields significantly as compared with an untreated control. Incomplete combinations or singlenutrient treatments did not significantly increase yields and, in some cases, decreased them. Yield increases were associated with increased fresh and dry weight. Although no significant effects of fertility on percentage of sapogenin were found, tubers in unfertilized plots contained the highest sapogenin in percentage.

\section{RESUMEN}

Durante tres años consecutivos se trataron plantas de Dioscorea composita con varias combinaciones de sulfato amónico, superfosfato y sulfato de potasa. Los tubérculos obtenidos de estas plantas fueron analizados para determinar su contenido de sapogenina. La aplicación de un abono completo 
aumentó significativamente la producción de sapogenina, al compararse con las plantas testigos. Los abonos incompletos o los tratamientos con un solo nutrimento no aumentaron significativamente la producción y en algunos casos la disminuyeron. Los aumentos en producción estuvieron asociados con el aumento a base del peso fresco y del peso seco, de los tubérculos. No se obtuvo resultados significativos en el porcentaje de sapogenina debidos a los tratamientos, pero sí hubo un porcentaje mayor de este compuesto químico en los tubérculos en las parcelas sin abonar.

\section{LITERATURE CITED}

1. Anon. Compendio de recomendaciones para la producción de cosechas, Agr. Expt. Sta. University of Puerto Rico, Misc. Pub. 1 (revised), 1954.

2. Duncan, D. B., New multiple range test, Biometrics 11: 1-42, 1955.

3. Irving, H., Fertilizer experiments with yams in Eastern Nigeria, 1947-1951, Trop. Agr. 38: 67-78, 1956.

4. Morris, M. P., Roark, B. A., and Cancel, B., Simple procedure for the routine assay of Dioscorea tubers, J. Agr. Food Chem. 6: 856-8, 1958.

5. Waitt, A. W., Yams, Dioscorea species, Field Crop Abs. 16: 145-57, 1963. 